\title{
Polityczność różnorodności jako problem hermeneutyczny
}

\begin{abstract}
Streszczenie: W dyskursie publicznym możemy zaobserwować wiele sposobów używania terminu „różnorodność” dlatego niezbędne są w tym zakresie, uporządkowanie pojęć, rzetelna, hermeneutyczna analiza dyskursu, będąca teoretycznym wprowadzeniem do dalszych, szczegółowych badań w ramach różnych dyscyplin i wskazanie jak ta wieloznaczność wpływa na praktykę polityczną.

W artykule poddane zostają analizie aspekty różnorodności o politycznym charakterze. Jego celem jest nakreślenie obszaru badawczego, obejmującego polityczny charakter różnorodności, postawienie i uzasadnienie pytań badawczych, które rozwijane będą w dalszych badaniach.

Ze względu na specyfikę wykorzystanych w badaniach danych i ich transdycyplinarnego charakteru oraz skrzyżowanie różnych punktów widzenia najbardziej odpowiednią metodą do ich analizy będzie metoda hermeneutyczna Hansa Georga Gadamera.

Punktem wyjścia może tu być hipoteza mówiąca, że ze względu na zmianę warunków funkcjonowania sfery publicznej takich jak: procesy globalizacyjne, powszechność edukacji, wzmożoną aktywność migracyjną zaobserwować można, iż reprezentanci różnych grup pozostający dotychczas w cieniu sfery prywatnej lub na obrzeżach sfery publicznej relokują swoją aktywność do jej centrum, zmieniając tym samym dynamikę demokratycznych systemów politycznych.
\end{abstract}

Słowa kluczowe: różnorodność, polityczność, włączenie, wykluczenie, pluralizm

$\mathbf{T}$ emat różnorodności podejmowany jest przez przedstawicieli nauk społecznych, humanistycznych, przyrodniczych i technicznych zarówno w badaniach teoretycznych, jak i stosowanych. Pojawia się w odsłonach: różnorodności kulturowej, społecznej, etnicznej, ale także bioróżnorodności czy neuroróżnorodności. Jednocześnie ze względu na wielość zawartych w swym obszarze pojęć i odwołań jest to temat nie do końca rozumiany. Sprawia kłopoty definicyjne, jak i interpretacyjne (Anand, Winters, 2008, s. 356), a przede wszystkim wzbudza kontrowersje i przynależy do zagadnień „trudnych” badawczo ${ }^{1}$.

W Polsce oprócz socjologicznych badań nad wykluczeniem i marginalizacją (Szafenberg, 2006; Galor, 2009), analiz z zakresu polityki społecznej (Sałustowicz, 2009, 2014), czy studiów feministycznych poświęconych dyskryminacji (Desperak, 2013, Chmura-Rutkowska, 2016), które to oscylują wokół osi wykluczenie-włączanie badań nad pluralizmem politycznym oraz badań wielokulturowości, tematyka różnorodności podejmowana jest głównie w dyscyplinie nauk o zarządzaniu (Leks-Bujak, 2014) i odnosi się do praktycznych jej zastosowań, gdzie łączona jest ze społeczną odpowiedzialnością przedsiębiorstw (Corporate Social Responsibility - CSR) oraz etyką biznesu (Adamczyk, 2009; Freemman, 2010; Grosser 2009; Jestrzębska, 2016).

${ }^{1}$ Socjologowie zwracają uwagę, że choć różnorodność stanowi potencjał dla rozwoju społecznego, to jednocześnie jest też zagrożeniem dla społecznej spójności (Giddens, 2007; Letki, 2008; Putnam, 2007). Na gruncie psychologii środowiskowej, różnorodność otoczenia jest jednym ze źródeł stymulacji, która może być zarówno pozytywna, jak i negatywna (Russell, 1988). 
Problematyka „zarządzania różnorodnością” oznacza dostrzeganie różnic między ludźmi i świadome rozwijanie strategii, polityk i programów, które tworzą klimat dla poszanowania i wykorzystania tych różnic. Jego celem jest stworzenie takiego środowiska pracy, w którym każda zatrudniona osoba czuje się szanowana i doceniana, i w którym może ona w pełni realizować swój potencjał, co przyczynia się do sukcesu organizacji (Bombiak, 2014). Różnica będąca nieodłącznym elementem organizacji, nie jest traktowana tu jako deficyt, lecz potencjał (Zaroda-Dąbrowska, 2015). Jakie konsekwencje dla tej definicji miałaby zmiana pojęcia „organizacja” na pojęcie „społeczeństwo” czy „państwo”?

\section{Wprowadzenie. Dlaczego idea różnorodności jest dziś tak istotna?}

Takie przejawy różnorodności jak: wiek, płeć, pochodzenie etniczne, wyznanie, sprawność fizyczna, status społeczny, czy orientacja seksualna w tradycyjnych organizacjach społeczno-politycznych funkcjonowały na marginesach sfery publicznej lub w sferze prywatnej i wielokrotnie stanowily podstawę do wykluczenia. W dzisiejszym świecie obserwujemy globalny proces przesunięcia reprezentantów różnorodności z peryferii sceny politycznej do jej centrum oraz rosnącą siłę głosu marginalizowanych dotąd mniejszości. I tu możemy odnieść się nie tylko do najbardziej spektakularnych w tym względzie przykładów obecności mniejszości etnicznych czy seksualnych w sferze publicznej, ale także do przedstawicieli różnego rodzaju niepełnosprawności, mieszczących się np. w zakresie neuroróżnorodności jak np. autyzm i przypadków walki rodziców dzieci autystycznych o godne dla nich miejsce w społeczeństwie. Są to głosy przenikające do współczesnego demosu. Czy współczesna liberalna demokracja za nimi nadąża? Czy nadąża za nimi współczesne państwo? A przede wszystkim czy nadąża za nimi nauka o polityce jako dyscyplina opisująca i analizująca życie polityczne?

Przez ostatnie trzydzieści lat odwoływaliśmy się w politologii do konstruktywnej wizji świata, idei integracji, solidarności i wspólnoty. Te wizje globalnej integracji² pojawiły się wraz z rozwojem procesów globalizacyjnych, nowych technologii i powstałego w ich konsekwencji „społeczeństwa ryzyka”. Paradoksalnie więc, powszechne odczuwanie ryzyka (Beck, 2002), sprzyjało potrzebie poczucia wspólnoty. Dlatego też globalne społeczeństwo obywatelskie opisywane jako wielopoziomowa, gęsto powiązana

${ }^{2}$ M. Walzer, Toward a Global Civil Society, New York 1995; A. Iriye, Global Community: The Role of International Organizations in the Making of the Contemporary World, Berkeley 2002; P. Singer, One World: The Ethics of Globalization, New Haven 2002; J. Kean, Global Civil Society?, Cambrigde 2003; M. Kaldor, The Global Ci vil Society. An Answer to War, Polity Press, Cambridge 2003; A. Etzioni, From Empire to Community: A New Approach to International Relations, New York 2004; Ü. Beck, E. Beck-Gernsheim, Miłość na odlegtość. Modele życia w epoce globalnej, Warszawa 2013; Ü. Beck, Społeczeństwo ryzyka. W drodze do innej nowoczesności, Warszawa 2002; Ü. Beck, Wtadza i przeciwwladza w epoce globalnej. Nowa ekonomia polityki światowej, Warszawa 2005; M. Castells, Sieci Oburzenia i nadziei. Ruchy społeczne w erze interentu, Warszawa 2013; M. Castells, Sita tożsamości, PWN, Warszawa 2008; M. Castells, Społeczeństwo sieci, Warszawa 2007; M. Castells, The power of Identity, Oxford 1997; M. Castells, The Rise of Network Society, Oxford 2000; D. Held ed., Global Transformations. Politics, Economics and Culture, Cambridge 1999; D. Held, Global Covenant. The Social Democratic Alternative to the Washington Consensus, Cambridge 2004. 
przestrzeń istniejąca $\mathrm{w}$ relacjach i dynamice społecznej, charakteryzuje pokojowe nastawienie i dążenie do wolności, równości i solidarności oraz koncentrowanie się wokół kategorii arystotelesowskiego dobra wspólnego, rozszerzonej z perspektywy polis na kosmos (Pietrzak, 2014).

Tymczasem wraz z kryzysem finansowym roku 2008, będącym jednocześnie zwiastunem kryzysu globalizacji, ale i wspomnianej konstruktywnej wizji świata, idea globalnej integracji zaczęła przygasać. Na jej miejsce wstępować zaczęła idea transnarodowości odwołująca się do państwa narodowego i tożsamości narodowej, ale przede wszystkim oparta na wielości. Transnarodowe społeczeństwo opiera się na pozapaństwowych, pozarządowych, niesuwerennych i nieterytorialnych uczestnikach, których działalność świadomie przekracza granice państw i wywiera wpływ na stosunki wewnątrzpaństwowe i międzynarodowe (Dumała, 1995, s. 196; Baylis, Smith, 2008, s. 24). By rozwiać lokalne problemy nie wystarcza dziś już działać lokalnie. Transnational networks to także nieformalne powiązania, łańcuchy migracyjne, organizacje religijne czy działalność przestępcza. I tu dochodzimy do pojęcia różnorodności, która paradoksalnie, za sprawą kryzysów, zaczęła wybrzmiewać coraz wyraźniej.

\section{Różnorodność jako problem badawczy}

Zjawisko różnorodności jest wszechobecne, poczynając od różnorodności biologicznej, a na systemie podatkowym kończąc. W praktyce politycznej i debacie publicznej często jest ono jednak ideologizowane i wykorzystywane do osiągania politycznych celów. Tymczasem w dzisiejszym świecie każdy, bez względu na poglądy polityczne, konfrontuje się z różnorodnością. Jednak by móc skutecznie sobie z nią radzić, trzeba uznać fakt jej istnienia oraz zrozumieć modele jej funkcjonowania. Dopiero to pozwoli na wprowadzanie skutecznych polityk i rozwiązań instytucjonalnych.

W dyskursie publicznym możemy zaobserwować wiele sposobów używania terminu „różnorodność”, i tłumaczenia go przez szereg odmiennych pojęć i znaczeń. Biorąc to pod uwagę, wydaje się, iż niezbędna jest w tym zakresie rzetelna, hermeneutyczna analiza będąca teoretycznym wprowadzeniem do dalszych, szczegółowych badań w ramach różnych dyscyplin. Wiąże się to także $\mathrm{z}$ demitologizacją pojęcia różnorodności i ukazaniem jego wszechobecności wraz z poszczególnymi konsekwencjami dla sfery publicznej, polityki, życia społecznego i gospodarczego.

Potrzebne jest tu zatem uporządkowanie znaczeń pojęcia i wskazanie jak ta wieloznaczność wpływa na praktykę polityczną. Za określonym rozumieniem stoi bowiem określona idea i praktyka polityczna wyrażająca się choćby w działaniu podmiotów publicznych i wprowadzaniu określonych rozwiązań prawnych. W praktyce często mamy do czynienia z mieszanką pojęć i koncepcji, dlatego tworzone są na ich podstawie niespójne polityki, które nie mogą być skuteczne. Dopiero bowiem polityczne uznanie różnorodności prowadzi do tworzenia praktycznej polityki na poziomie rynku pracy, szkolnictwa, ochrony zdrowia, czy świadczeń społecznych.

Punktem wyjścia może tu być hipoteza mówiąca, iż reprezentanci różnych grup pozostający dotychczas w cieniu sfery prywatnej lub na obrzeżach sfery publicznej relokują swoją aktywność społeczno-polityczną do jej centrum, zmieniając tym samym dynami- 
kę demokratycznych systemów politycznych. Do relokacji tej dochodzi ze względu na zmianę warunków funkcjonowania sfery publicznej takich jak: procesy globalizacyjne, powszechność edukacji, czy wzmożona aktywność migracyjna.

Powyższą hipotezę pomóc mogą weryfikować pytania takie jak: Czym jest różnorodność i jakie jest jej znaczenie dla polityki? Jak współczesna liberalna demokracja radzi sobie z naporem różnorodności? Czy w perspektywie politycznej możliwe jest postrzeganie różnorodności jako potencjału, a nie tylko w perspektywie antydyskryminacyjnej? W jaki sposób poszczególne sfery społeczne i polityczne radzą sobie ze zjawiskiem różnorodności ze względu na czynniki je warunkujące (takie jak: płeć, wiek itp.)? Wreszcie, jakie są możliwe kierunki rozwoju przyszłych polityk społecznych by jak najlepiej realizowały swe cele ze względu na poszczególne aspekty różnorodności?

Jeżeli przyjmiemy, że praktyka polityczna to działania mieszczące się w polityce (politics), czyli w sposobie rządzenia (governance), ale też i poza ten obszar wykraczające w stronę polityczności (the political), czyli norm społecznych ${ }^{3}$, praktyka polityczna odnosi się do działań obejmujących politykę rządu, wertykalnej relacji między rządzącymi a społeczeństwami, ale także do sporów o sposób organizacji życia publicznego, w związku z tym określona polityka społeczna, kulturalna, czy edukacyjna jest tylko odbiciem określonej konfiguracji polityczności, zaś praktyka polityczna to relacja między polityką i politycznością. Polityczność jest więc pojęciem szerszym niż polityka (Karwat, 2010, s. 64, 70.)

Celem badań nad różnorodnością byłoby więc na początku uporządkowanie znaczeń pojęcia „różnorodność” i wskazanie jak ta wieloznaczność wpływa na praktykę polityczną, a następnie ukazanie sposobów politycznego wykorzystania tegoż pojęcia. Za określonym rozumieniem stoi bowiem określona idea i praktyka polityczna wyrażająca się choćby w działaniu podmiotów publicznych i wprowadzaniu określonych rozwiązań prawnych. W praktyce często mamy do czynienia z mieszanką koncepcji, dlatego tworzone są na ich podstawie niespójne polityki, które nie mogą być skuteczne.

\section{Polityczność różnorodności}

W związku z powyższym wywodem, jednym z podstawowych dla politologów pytań, staje się pytanie o przyczyny uznawania różnorodności za zagadnienie polityczne. Odpowiedź na nie znaleźć możemy w co najmniej kilku obszarach. Wyodrębnione tutaj to: 1) wielość (plurality), 2) wspólnota, 3) prawa człowieka, 4) wielokulturowość,

${ }^{3}$ W ramach myśli politycznej możemy wyróżnić dwa nurty związane z podejściem do norm i wartości w przestrzeni publicznej (Geertz, 1973). Pierwszy z nich inspirowany jest debatą prowadzoną w ramach studiów feministycznych i wiąże się z ideą komunitaryzmu (Naser, Honneth, 2003; Taylor, 1994; Walzer, 1983). Drugi zaś odnosi się do debat toczonych w ramach filozofii liberalnej (Rawls, 1971). Komunitarianie twierdzą, że normy i wartości są podstawą wspólnoty politycznej i uznają, że normy reprezentowane przez mniejszości powinny znaleźć odzwierciedlenie w systemie politycznym w postaci prawnej i społecznej reprezentacji, nawet jeśli mogą budzić kontrowersje. W nurcie liberalnym dochodzi natomiast do rozdzielenia sfery prywatnej i publicznej, a za regulację życia publicznego odpowiada świeckość sfery publicznej, indywidualizm i prawa człowieka. Dyskusja między przedstawicielami tych dwóch nurtów, a więc komunitarianami i liberałami odnosi się właściwie do kwestii uznawania odmienności normatywnych w sferze publicznej. 
5) różnicowanie (the process of othering). Wszystkie zawierają w sobie pewne napięcie. Na polu ontologii odnosi się ono do pytania o człowieczeństwo, które w aspekcie politycznym wiąże się z prawami politycznymi, czyli obywatelstwem. Na polu aksjologii mieści ono w sobie pytanie o wartości przypisane obywatelstwu oraz ich brak w sytuacji wykluczenia z obywatelstwa. Na polu epistemologii odnosi się do metodologii i pytań jak ową polityczność różnorodności, a także i różnorodność polityczną badać. Przedstawmy zatem w kilku zadaniach argumentację potwierdzającą, że obszary te mogą być interesujące dla politologicznych badań nad różnorodnością.

1. Wielość. Wprowadzeniem w zagadnienie polityczności różnorodności może być analiza politycznego charakteru wielości zaproponowana przez Hannę Arendt. Autorka Kondycji ludzkiej postrzega istotę wielości (różnorodności) jako akt założycielski teorii polityki. Według Arendt ludzka wielość zaznaczona w akcie stworzenia (Bóg nie stworzył człowieka, a mężczyznę i niewiastę) konstytuuje zoon politikon dziedziną polityczną. Żadna ludzka istota zatem nigdy nie istnieje w pełni pojedynczo, a fakt ów nadaje polityczne znaczenie mówieniu i działaniu jako czynnościom, które podlegają wpływowi wielości i są poza nią nie do pomyślenia. Ludzka wielość nie jest bowiem ani wielością przedmiotów, wykonanych według jednego wzoru, ani wielością odmian w obrębie gatunku biologicznego. Nie istnieje więc człowiek jako taki, istnieją tylko mężczyzna i kobieta, którzy w swojej absolutnej odmienności są sobie równi. Wspólna ludzka tożsamość jest więc równością, przejawiającą się w absolutnej odmienności tych, którzy są sobie równi. O ile mówienie i działanie są dwoma zasadniczymi czynnościami politycznymi, o tyle odmienność i równość to dwa podstawowe ciała polityczne (Arendt, 2005). Stąd także Arendiańska koncepcja polityki jako działania symfonicznego. Arendt opowiada się za rehabilitacją polityki, która wzięłaby na siebie zapewnienie równości, wielości i różnorodności wszystkich ludzi.

2. Wspólnota. Polityczność jako zasada organizacji życia odnosi się także do dyskusji nad konstruowaniem wspólnoty i określaniem jej granic. Różnorodność w odniesieniu do praktyki politycznej polega na zdefiniowaniu zasad, według których przebiegać mają relacje między reprezentantami tzw. mainstreamu a przedstawicielami poszczególnych mniejszości. Kluczowe jest tu zdefiniowanie terminu mainstreamu, czyli grupy dominującej oraz określenie jak ma się ona do wspólnoty politycznej. Jeśli wspólnota ta określana jest według wąsko zdefiniowanych kryteriów grupy dominującej, także wspólnota polityczna ograniczy się do grupy dominującej, a tym samym do wykluczania z niej Innych. Jeśli natomiast wspólnota polityczna odnosić się będzie raczej do zasad i norm niż do ideologicznego ujęcia, jej granice będą bardziej elastyczne, gdyż mogą być poddawane dyskusji i modyfikowane (Geertz, 2005). Różnorodność może odnosić się w tym sensie do sposobu regulowania procesów włączania i wykluczania na poziomie debaty publicznej oraz działań w przestrzeni publicznej. Praktyka polityczna często instrumentalnie wykorzystuje różnorodność w sferze publicznej. Przejawia się to niechęcią do Innego, a nawet jej podsycaniem w celu osiągnięcia korzyści politycznych lub partyjnych.

3. Prawa czlowieka. Europejska debata o różnorodności społecznej toczyła się równolegle do dyskusji o prawach człowieka (Kymlicka, 2007), których historia wiąże się z konstrukcją nowego ładu międzynarodowego po $1945 \mathrm{r}$. Bezpośrednio po II wojnie światowej kwestie mniejszości narodowych i etnicznych zeszły na dalszy plan, a centrum 
zainteresowania politycznego stała się jednostka. Prawa człowieka zinstytucjonalizowano jako prawa jednostki. Problem mniejszości kulturowych został w ten sposób wykluczony poza debatę polityczną, a system ochrony prawnej popierany przez ONZ wspierał jednostki, a nie prawa grup mniejszościowych. Wiele kręgów politycznych akceptowało taki stan rzeczy, gdyż był on korzystny dla stabilności demokracji (Kymlicka 2007, 30). Istnienie mniejszości narodowych postrzegano jako potencjalne zarzewie konfliktów, wspomagano więc tworzenie ładu opartego na homogenicznych wspólnotach narodowych. Sytuacja zaczęła się zmieniać pod koniec lat 80. XX wieku. W 1989 przyjęto pierwszy dokument uznający wielokulturową rzeczywistość i uznający prawa jednostek należących do określonych grup etnicznych (Konwencja 169 Międzynarodowej Organizacji Pracy: dotyczaca ludności tubylczej i plemiennej w krajach niezależnych). Kolejne dokumenty to np. prace Komitetu ONZ dotyczące Dyskryminacji Rasowej, działania UNESCO, a dekada 1995-2004 ogłoszona została dekadą ludności tubylczej. Lata 90-te przyniosły nowe prawa w tym względzie, np. prawo do posługiwania się językiem ojczystym oraz prawo do ochrony dziedzictwa kulturowego, nie towarzyszyło jednak tworzenie mechanizmów instytucjonalnych i egzekwujących je procedur. Wprowadzenie tych kwestii do dyskursu publicznego spowodowało jednak zmianę w sposobie postrzegania problemu przez gremia sprawujące władzę i obecnie nie traktuje się już kwestii różnorodności jako zagrożenia dla demokracji (Kymlicka, 2007, s. 43). Uznanie praw mniejszości stało się międzynarodowym standardem prawnym i politycznym ${ }^{4}$, a prawa mniejszości zakorzenione są w systemach prawnych państw przez ich relację do prawa międzynarodowego i członkostwo $\mathrm{w}$ organizacjach ponadnarodowych, które to mogą wpływać na ich przestrzeganie.

Ważnym głosem w kwestii różnorodności jest także głos badaczy zajmujących się prawami mniejszości i ich uznaniem oraz relacją z marginalizacją ekonomiczną. Brak uznania dla określonych mniejszości w sferze publicznej przekłada się bezpośrednio na ich marginalizację ekonomiczną (Sommers, 2008). Dlatego termin różnorodność społeczna, oprócz wspomnianych wyżej, obejmuje także różnice w statusie ekonomicznym. Oprócz dyskryminacji dotykającej np. przedstawicieli różnorodności kulturowych dotknięci są oni także dyskryminacją ekonomiczną. Jest to tak zwana dyskryminacja krzyżowa. Pojawia się w tej dyskusji w związku z tym pytanie, czy w polityce wobec różnorodności społecznej stawiać należy na uznanie, czy redystrybucję?

4. Wielokulturowość. Życie przedstawicieli różnych kultur pod jednym dachem wspólnych państw jest faktem. Termin ,wielokulturowość” jako przykład różnorodności społecznej używany był $\mathrm{w}$ związku $\mathrm{z}$ tym $\mathrm{w}$ ramach stosowania rozmaitych taktyk i zaspokajał określone zapotrzebowanie polityczne (Parekh, 2000). Sposób w jaki dyskutowano o różnorodności i wielokulturowości spowodował zatarcie różnicy między deskryptywnym a normatywnym ujęciem zjawiska. Forma debaty publicznej ma swoje znaczenie symboliczne, gdyż polityczne uznanie faktu różnorodności prowadzi do dalszych kroków, czyli tworzenia polityki na rzecz wyrównywania szans różnych społeczności zamieszkujących państwo. Taka polityka integracyjna to zestaw rozwiązań systemowych umożliwiających równe uczestnictwo wszystkich obywateli i obywatelek

\footnotetext{
${ }^{4}$ Różnorodność w sensie prawnym odwołuje się do uznania różnorodności społecznej na poziomie przepisów prawnych, których celem jest niwelowanie różnicy między grupą dominującą a grupą mniejszościową za pomocą dostępu reprezentantów tych grup do katalogu praw i wolności.
} 
w życiu państwa. Są to rozwiązania na poziomie regulacji rynku pracy, szkolnictwa, ochrony zdrowia, świadczeń społecznych, a także debata publiczna o normach i wartościach reprezentowanych $\mathrm{w}$ danym społeczeństwie.

5. Rozróżnianie (the proces of othering). Na szczególe uwzględnienie zasługuje tutaj proces różnicowania, choć polskie tłumaczenie nie do końca oddaje charakter angielskiego othering. Jest to proces przypisywania grupie lub jednostce w roli Innego i tworzenia własnej tożsamości w opozycji do niego 5 . Typowym przykładem takiego etykietowania są starożytni barbarzyńcy, czyli wszyscy niebędący Grekami. W ostatnich latach zaobserwować możemy pewną łatwość, z jaką przymiotnik „inny” (other) przekształcił się w czasownik „othering”, co wskazuje na siłę tego terminu, zajmującego ważną pozycję w dyskursie feministycznym, postkolonialnym i dotyczącym praw obywatelskich.

Othering to proces, który wykracza poza znany i opisany mechanizm kozła ofiarnego (Girard, 1987) i pozbawia innych cech charakterystycznych dla „tego samego”, rozumu, godności, miłości, dumy, heroizmu, szlachetności, a ostatecznie wszelkich praw człowieka. Niezależnie od tego, czy Inny jest grupą rasową czy religijną, grupą płciową, mniejszością seksualną, czy narodem. Othering może przyjąć formę wyzysku, ucisku, a nawet ludobójstwa, zaprzeczając naturalnej koncepcji praw człowieka, ponieważ - jak to określił Richard Rorty - wszystko zmienia to, kto liczy się jako bliźni przynależący do naszej wspólnoty moralnej (Rorty, 1993, s. 124).

Wiele współczesnych dyskursów na temat Innego postrzega relacje między ludźmi w sposób niezwykle pesymistyczny, poczynając od Hobbsowskiego homo homini lupus est. Niektórzy autorzy zwłaszcza Said $(1985,1994)$ twierdzili, że zachodnia tożsamość i kultura są fundamentalnie ukształtowane przez logic of othering, która dehumanizuje lub dewaluuje innych ludzi, takich jak prymitywni, niecywilizowani, orientalni, czarni, niewierzący, kobiety i tak dalej. Istotną cechą tej logiki jest odmawianie Innemu głosu, odmawianie mu możliwości wypowiadania się w swoim imieniu, a zamiast tego przypisywanie cech, opinii i poglądów odnoszących się do własnej tożsamości i kultury.

To, czy można przemawiać w imieniu Innego, którego głos został uciszony, stało się przedmiotem gorącej debaty. Dyskutowaną kwestią jest to, czy można przekroczyć „wyobcowanie" i nawiązać prawdziwe porozumienie z Innym, bądź to za pomocą rozumu (poprzez odwołanie się do wspólnego człowieczeństwa, jak Kant), czy za pomocą empatii (poprzez odwołanie się do współczucia i uczucia do cierpień innych, jak Hume i Schopenhauer). Być może nadszedł czas, by uznać Innego za podmiot zróżnicowany i złożony - potencjalnego wroga i ofiarę, model naśladowania i identyfikacji, obiekt troski i podmiot własnego losu, a przede wszystkim uznać, że Inny może mieć wiele twarzy.

\section{Dlaczego polityczność różnorodności to problem hermeneutyczny?}

Problem hermeneutyczny pojawił się w momencie, gdy człowiek zaczął mówić. Hermeneutyka to próba zrozumienia Innego. Dlatego proponowaną metodą badawczą będzie tu hermeneutyka Hansa Georga Gadamera. Struktura hermeneutycznej analizy

${ }^{5}$ Pisze o tym między innymi Stanisław Konopacki w odniesieniu do tożsamości europejskiej budowanej w opozycji do inności. S. Konopacki, Obywatelstwo europejskie w kontekście członkostwa Polski w Unii Europejskiej, Łódź 2005. 
zastosowanej w badaniach nad różnorodnością może opierać się na trzech poziomach. Po pierwsze, na poziomie subinterpretacji - tzn. w jaki sposób człowiek (tożsamość) doświadcza, odbiera i kształtuje własne rozumienie tego, co go spotyka w danych mu kategoriach kulturowych, po drugie - na poziomie sfery publicznej, czyli jak owe doświadczenia w formie kulturowych ekspresji tworzą powszechny i wspólnotowy czy grupowy obieg wiedzy, świadomości i systemu wartości, tzn. dyskurs publiczny, po trzecie - na poziomie meta-praktyk, tzn. jak ów dyskurs czy dyskursy publiczne, są przetwarzane na polityki publiczne.

Tak prowadzone badania pozwolą na opisanie przemian zachodzących w sferze publicznej, w której centrum za sprawą procesów społeczno-politycznych pojawili się reprezentanci różnorodności. Hermeneutyczna analiza dyskursów różnorodności stworzy ramę pojęciową dla dotychczasowej wiedzy o obserwowalnych faktach i zjawiskach kulturowo-społeczno-politycznych, ale także i interpretacji funkcjonujących w sferze publicznej dyskursów jak np. publicystyka, media, zarządzanie różnorodnością.

Zjawisko różnorodności społecznej jest bardzo aktualnym tematem, wartym nie tylko badań, ale i mającym bogaty kontekst edukacyjny. Z różnorodnością spotykamy się bowiem na co dzień w środowisku organizacji międzynarodowych, transnarodowych korporacji i relacji zarówno w aspekcie kultury, religii, różnic etnicznych, płciowych, wieku, orientacji, światopoglądu, czy preferencji dotyczących stylu życia. Przyczynia się ono również do zwiększania świadomości społecznej w zakresie radzenia sobie z radykalizacją życia politycznego i populizmem.

Martin Buber (1993) pisał, że rozwój ludzkości to naprzemienne okresy zadomowienia, kiedy ludzie czują się bezpieczni i jasno widzą przyszłość oraz bezdomności, kiedy czują się niepewni jutra i pełni lęku. Współczesny świat wkroczył w czas bezdomności, jakkolwiek wolimy nazywać go kryzysem. Ta symboliczna bezdomność objawia się wspomnianą radykalizacją życia społeczno-politycznego, ksenofobią, islamofobią i przemocą w sferze publicznej.

Pośród największych wyzwań współczesnego świata problemy wprost odnoszące się do różnorodności zajmują czołowe miejsca. Co by się stało gdybyśmy przestali myśleć o nich w kategoriach problemów i rozwiązań? (Bauman, Bauman, Kociatkiewicz, Kostera, 2017). Czy szukanie rozwiązań, gdy nie uzgodni się wspólnej definicji problemu nie jest bezcelowe? Potrzebujemy zatem badań naukowych opartych na głębokim humanistycznym namyśle, które pomogą konstruktywnie pokonać czas interregnum. Do takich należą hermeneutyczne badania różnorodności.

\section{Bibliografia}

Adamczyk J. (2009), Społeczna odpowiedzialność przedsiębiorstw: Teoria i praktyka, PWE, Warszawa. Anand R., Winters M. (2008), A Retrospective View of Corporate Diversity Training from 1964 to the Present, „Academy of Management Learning and Education”, vol. 7/3. 
Arendt H. (2005), Polityka jako obietnica, Wydawnictwo Prószyński i S-ka, Warszawa.

Batliwala S., Brown L. D. (2006), Transnational Civil Society: An Introduction, Bloomfield CT.

Bauman Z., Bauman I., Kociatkiewicz J., Kostera M. (2017), Zarządzanie w płynnej nowoczesności, Wydawnictwo Bęc zmiana, Warszawa.

Baylis J., Smith S. (2008), Globalizacja polityki światowej. Wprowadzenie do stosunków międzynarodowych, Kraków.

Beck Ü. (2002), Społeczeństwo ryzyka. W drodze do innej nowoczesności, Warszawa.

Beck Ü. (2005), Władza i przeciwwładza w epoce globalnej. Nowa ekonomia polityki światowej, Warszawa.

Beck Ü., Beck-Gernsheim E. (2013), Miłość na odległość. Modele życia w epoce globalnej, Warszawa.

Blok A. (2001), Honour and violence, Polity, Cambridge.

Bombiak E. (2014), Zarządzanie różnorodnościa wyzwaniem dla wspótczesnych menedżerów, Zeszyty Naukowe Uniwersytetu Humanistyczno-Przyrodniczego w Siedlcach, „Administracja i Zarządzanie", nr 102.

Brown L. D. (2008), Creating Credibility: Legitimacy and Accountability for Transnational Civil Society, Bloomfield CT.

Buber M. (1993), Problem człowieka, PWN, Warszawa.

Castells M. (1997), The power of Identity, Oxford University Press, Oxford.

Castells M. (2000), The Rise of Network Society, Oxford University Press, Oxford.

Castells M. (2013), Sieci oburzenia i nadziei. Ruchy społeczne w erze interentu, Warszawa.

Chmura-Rutkowska I., Duda M., Mazurek M., Sołtysiak-Łuczak A. (2016) Gender w podręcznikach, Fundacja Feminoteka, Warszawa.

Desperak I. (2013), Pteć zmiany: Zjawisko transformacji w Polsce z perspektywy Gender, Wydawnictwo Uniwersytetu Łódzkiego, Łódź.

Dumała A. (1995), Uczestnicy transnarodowi - podmioty niezależne czy kontrolowane przez państwa?, w: Państwo we współczesnych stosunkach międzynarodowych, red. E. Haliżak, I. PopiukRysińska, Warszawa.

Etzioni A. (2004), From Empire to Community: A New Approach to International Relations, New York.

Florini A. (red.), (1999), The Third Force: The Rise of Transnational Civil Society, Tokyo-Washington.

Friedman A. L., Miles S. (2006), Stakeholders. Theory and Practice, Oxford University Press, Oxford.

Gadamer H.-G., (1976), Philosophical Hermeneutics, University of California Press, Berkeley.

Gadamer H.-G., (1989), Truth and Method, Crossroad, New York.

Geertz C. (2005), Interpretacja kultur. Wybrane eseje, Wydawnictwo UJ, Kraków.

Geertz C. (1973), Ideologia jako system kulturowy, Wydawnictwo UJ, Kraków.

Girard R. (1987), Kozioł ofiarny, Łódź.

Grosser K. (2009), Corporate social responsibility and gender equality: women as stakeholders and the European Union sustainability strategy, „Business Ethics: A European Review”, 18/3.

Grudzińska A. (2015), Nieboszczka wielokulturowość, czyli o jakiej „,wielokulturowości” debatuje Europa?, w: (nie) widzialne granice. O tym co dzieli i łączy w wielokulturowości, red. K. Kubin, Fundacja na Rzecz Różnorodności Społecznej, Warszawa.

Held D. (1999), Global Transformations. Politics, Economics and Culture, Cambridge.

Held D. (2004), Global Covenant. The Social Democratic Alternative to the Washington Consensus, Cambridge. 
Iriye A. (2002), Global Community: The Role of International Organizations in the Making of the Contemporary World, Berkeley.

Jastrzębska E. (2016), Zarządzane różnorodnościa jako element CSR - dobre praktyki i korzyści, „Marketing i rynek", $\mathrm{nr} 8$.

Kaldor M. (2003), The Global Ci vil Society. An Answer to War, Polity Press, Cambridge.

Karwat M. (2010), Polityczność i upolitycznienie. Metodologiczne ramy analizy, „Studia Politologiczne", nr 17, s. 63-88.

Kean J. (2003), Global Civil Society?, Cambrigde.

Konopacki S. (2005), Obywatelstwo europejskie w kontekście członkostwa Polski w Unii Europejskiej, Wydawnictwo Uniwersytetu Łódzkiego, Łódź.

Kymlicka W. (2007), Multicultural odysseys:Navigating the New International Politics of Diversity, Oxford University Press, Oxford.

Leks-Bujak E. (2014), Zarządzanie różnorodnościa w organizacji, „Zeszyty Naukowe Politechniki Śląskiej, Organizacja i Zarządzanie”, z. 72 (1918).

Letki N. (2008), Does diveristy erode social cohesion? Social capital and race in British neighbourhoods, „Political Studies”, 56 (1), s. 99-126.

Naser N., Honneth A. (2003), Redistribution or recognition?:A political-Philosophical Exchange, Verso, London-New York.

Parekh B. (2000), Rethinking Multiculturalism: Cultural Diversity and Political Theory, Macmillan, Basingstoke.

Pietrzak E. (2014), Ku globalnemu społeczeństwu obywatelskiemu. Transgresje idei, Dom Wydawniczy Elipsa, Warszawa.

Putnam R. D. (2007), E Pluribus Unum: Diversity and Community in the Twenty-First Century, „Scandinavian Political Studies", vol. 30, no. 2.

Rawls J. (1971), A Theory of Justice, Oxford University Press, London.

Rorty R. (1993), Human rights, rationality and sentimentality, w: On human tights, red. S. Shute, S. Hurley, Basic Books, New York.

Russell K. (1988), The color of crime, New York University Press, New York.

Said, E. W. (1985), Orientalism, Penguin, Harmondsworth.

Said E. W. (1994), Culture and imperialism, Chatto and Windus, London.

Sałustowicz P. (2009), Pomoc społeczna w wybranych krajach Unii Europejskiej, Instytut Rozwoju Służb Publicznych., Warszawa.

Sałustowicz P. (2014), Afirmacja czy Kontestacja? Dylemat spoteczeństwa kapitalistycznego w kryzysie, Societas Pars Mundi, Bielefeld.

Singer P. (2002), One World: The Ethics of Globalization, New Haven.

Sommers M. (2008), Genenealogies of Citizenship. markets, Statelessness and the Rights to have Rights, Cambridge University Press, Cambridge-New York.

Szafanberg R. (2006), Marginalizacja społeczna i wykluczenie. Wykłady, Instytut Polityki Społecznej UW, Warszawa.

Taylor C. (1994), Multiculturalism and the Politics of Recognition, Princeton University Press, Princeton.

Walzer M. (1983), Sphers of Justice: a Defence of Pluralism and Equality, Basic Books, New York.

Walzer M. (1995) Toward a Global Civil Society, New York,

Zarodoa-Dąbrowska A. (2015), Zarządzanie różnorodnościa jako wyzwanie menedżerów. Wykorzystanie potencjału starszych pracowników - case study (2015), w: Wybrane problemy w ksztattowaniu zachowań organizacyjnych, red. M. Makowiec, Uniwersytet Ekonomiczny w Krakowie, Kraków. 


\title{
Politics of Diversity as a Hermeneutical Problem
}

\begin{abstract}
Summary
In public discourse we can observe many ways of using the term "diversity", therefore it is necessary in this respect to organize the concepts and a reliable, hermeneutical analysis of the discourse, which is a theoretical introduction to further, detailed research in various disciplines and an indication of how this ambiguity affects political practice.

In the article will be analysed aspects of political diversity. The aim of the article is to outline a research area, including the political nature of diversity, posing and justifying research questions, which will be developed in further research. Due to the specificity of the data used in the study, their transdisciplinary character and the intersection of different points of view, the hermeneutical method by Hans Georg Gadamer will be the most appropriate method for their analysis.

The starting point here may be the hypothesis that due to the change in the conditions of functioning of the public sphere, such as globalisation processes, widespread education and increased migration activity, it can be observed that representatives of various groups who have remained in the shadow of the private sphere or on the outskirts of the public sphere are relocating their activity to its centre, thus changing the dynamics of democratic political systems.
\end{abstract}

Key words: diversity, politics, inclusion, exclusion, pluralism 
